\title{
ASSESSMENT OF THE PHYSICAL EDUCATION ACTIVITY CONCERNING THE OPTIMISATION OF INTERPERSONAL BEHAVIOUR
}

\author{
Gabriel TUDORACHE ${ }^{1 *}$, Liliana MIHĂILESCU ${ }^{1}$ \\ ${ }^{1}$ University of Pitești, Faculty of Science, Physical Education and Informatics, Pitești, Romania \\ *Corresponding author: gaby_91_pit@yahoo.com
}

DOI: https://doi.org/10.51267/icpesk2020bp15

\begin{abstract}
The paper assesses the abilities of second-grade students for physical education activities, with the aim of developing their psychological and social attitudes that are necessary for their integration into the community. The design of the educational activity for the second grade, which is achieved through the means of dynamic games, aims at developing and educating psychomotor skills but also optimising the psychological and social attitudes needed to build the social behaviour of students. Participants in the research are 81 students aged 8 to 9 years. The sociometric method was used to assess the dynamic of the sociability level and the intensity of existing relationships between students in the physical education lesson in order to track the formation of their prosocial behaviour during the basic acquisition cycle. In this respect, two sociometric types of tests were designed (according to the model of Zlate, 1982), which were applied differently: a written assessment - a sociometric questionnaire; a written paper - the practice of the sociometric questionnaire, as well as a practical test - the dynamic game. After analysing and comparing the final data with the initial ones through the two tests following the didactic strategy, we can conclude that the interpersonal relationships between students have reached a level of social maturity in school, while the level of group cohesion is reflected in the unity of the group rather than the person.
\end{abstract}

Keywords: sociometry, assessment, physical education, interpersonal relationships, group cohesion.

\section{Introduction}

The contemporary society's dream implies the presence of socially active people. Philosophical, sociological, psychological and pedagogical studies show that social activity is not generated spontaneously and deliberately, but its formation and development begin from preschool age (Ivanova \& Timoshina, 2012). Formation and development are processes that go on throughout our lives and involve different aspects (physical, motor, cognitive, intellectual, emotional ones), which are interrelated and interdependent (Diamond, 2007).

Vasiliu (2015) considers that physical education and sport contribute to the quality of life influencing emotional states, peer relationships, material wealth (employees are more relaxed, have good physical and mental tone, are more productive), independence and social integration. Lupu (2006) also emphasises the dimensions of the quality of life: emotional or mental wellbeing, interpersonal relationships, material wealth, self-assertion, physical well-being, independence, social integration, ensuring fundamental human rights.

Physical education is one of the compulsory school subjects included in the framework plan for primary education. This subject has a unique characterisation regarding the formation of students' profile, in the sense that the specialised teacher uses a different approach compared to the others, which includes a didactic strategy focused on the body-movement relationship to achieve the proposed contents and general skills (D'Isanto, 2019). General skills generate 
content domains that are projected and integrated in the didactic strategies used by teachers (Mihăilescu \& Mihăilescu, 2017). General skill as a social characteristic, which is presented to discuss the content domain "Development of personality features" and is already used in the curriculum for the basic knowledge cycle, is intended to form and develop an interpersonal behaviour based on improving the interaction between group members and increasing their degree of cohesion through dynamic games.

Physical education in the basic acquisition cycle recommends the game as a means of instruction for the progressive development of skills by exploiting the age-specific experience of students and emphasising the emotional dimensions of their personalities (Urichianu, 2017). Thus, dynamic games manage to influence student's mind and social participation, improving their self-confidence, physical and psychological condition, solidarity and trust.

The physical education class disposes of all necessary resources (means, room, content, forms of organization) to develop and use an educational design with game-based learning contents in order to improve interpersonal relationships and the level of cohesion (Mijaică, 2015). Psychomotor activities within the physical education class offer a long-term socialisation character to interpersonal relationships, playing a huge role in the formation of a compatible social attitude (Cârstea, 1981).

The development of interpersonal relationships and group cohesion includes everything that sums up social integration. Interpersonal relationships represent the connections that are formed between different individuals and not only, but also the connections between certain groups. Group cohesion expresses the nature of the group, the way in which its members concentrate their interactions for a unified goal. (Tudorache \& Mihăilescu, 2018)

The research by Sopa et al. (2014) applies the sociometric method to the physical education system in order to induce behavioural changes as a result of using dynamic games. Another research (Rukavishnikova, 2016) confirms the reciprocity between communication acts in creating an emotional climate favourable to game groups and the contribution of game activity to forming selective preferences among children. Usinski (1956) states that all human aspects are formed through the game: the human mind, heart, and will. The future character of children is influenced by games because they can determine them to express their inclinations and strengths, and also to develop their skills and true vocation.

Lupu (2011) confirms the hypothesis according to which properly organising game-based learning situations since childhood is vital for progressive acquisitions, not only physical but also intellectual ones.

Educating the student within an organised process that involves "the transmission of professionally expressed information will generate a correct body posture, an appropriate attitude, a positive overall state" (Plăstoi \& Buțu, 2018, p. 1358), which leads to beneficial socialisation that contributes to increasing the physical ability of students.

Developing the social climate during classes throughout a basic acquisition cycle is constantly and progressively monitored by the teacher in order to identify the social relationships involving several members who cooperate to reach game-related common goals (Mijaică, 2016).

The correctness and efficiency of the teaching-learning process are given by the nature of behavioural changes as a result of the activity carried out. Skill development aims to produce 
behavioural changes and is the outcome of the activities performed during the physical education class.

Purpose of study

The aim of the research is to use the sociometric method as an assessment instrument to identify the level of interpersonal relationships and improve group cohesion in the second grade for the physical education school subject in order to establish how much the dynamic games have contributed to the achievement of a general skill, socially speaking.

\section{Methodology}

The research is a long-term experimental study that lasted during a semester in 2018-2019. To verify the hypothesis that the game method and the practice of dynamic games during the physical education class determine prosocial behaviours and the formation of an established skill in primary school students, the didactic strategy was exclusively focused on dynamic games (36) and sport routes (7), which were used in all steps of a lesson throughout the experiment. All themes provided in the physical education lessons, both the psychomotor and psychosocial ones, were achieved only through dynamic games and application routes.

We share the opinion that behavioural changes can be estimated only by applying an assessment or an assessment system. To establish the level of general skill acquisition from a social point of view, we proposed the "Shaping of socio-emotional behaviour based on the feelings of friendship, collaboration and cooperation in the psychomotor activity" to create a balance between the general skill and an interdependent content domain. For the "Development of personality features", which is included in the curriculum, two tests were designed on the basis of the sociometric method to determine the dynamic of the process of optimising an interactive behaviour for second-grade students.

The research sample consisted of students in three second-grade classrooms from three schools: "Nicolae Bălcescu" School no. 6 in Pitești, "Ion Luca Caragiale” School no. 16 in Pitești and School no. 1 in Costești. The number of students is different in the two tests due to the transfers occurring between the two semesters (Table 1).

Table 1. Number of participants in initial and final testing

\begin{tabular}{lcccccc}
\hline \multirow{2}{*}{ Educational establishment } & \multicolumn{3}{c}{ Initial test (IT) } & \multicolumn{3}{c}{ Final test (FT) } \\
\cline { 2 - 6 } & Girls & Boys & Total & Girls & Boys & Total \\
\hline "Nicolae Bălcescu" Middle School no. 6, Pitești & 17 & 13 & 30 & 16 & 13 & 29 \\
"Ion Luca Caragiale" Middle School no. 16, Pitești & 12 & 13 & 25 & 12 & 14 & 26 \\
Middle School no. 1, Costești & 5 & 21 & 26 & 5 & 21 & 26 \\
\hline
\end{tabular}

Although the written test is not recommended in the physical education class during the basic acquisition cycle, we adjusted the initial form of the questionnaires as well as their presentation for students using capitals so that they can better read and understand.

The test "My own opinions" is a two-item questionnaire following all the steps of Zlate (1972), in which each student is asked to express three likes and three dislikes: 
1. Which classmates would you choose to help you or support you to draw a huge picture/ do an important project? List these classmates in order of preference;

2. Which classmates would be unsuitable to join you to draw a huge picture/ do an important project? List these classmates in order of dislike.

With this test, we can assess the types of positive or negative interactions, which also shows us each student's position in the classroom and the level of group cohesion, without involving the active motor nature of the physical education class.

The test "My own revised/changed opinions", almost like the first one, consists of a sociometric questionnaire following the steps of Zlate (1972). The difference between the two tests is the active motor nature of the physical education class emphasised in the content of the two items of the questionnaire through the student's participation in a test (a dynamic game, which implies cooperation, involvement and collaboration) and, on the other hand, the way of organizing it for the second-grade students, which involves two phases:

- the first phase: applying the test before the dynamic game - initial test:

1. Name 3 classmates with whom you would like to make pairs to take part in the dynamic game "Pass the ball". Name them in order of preference.

2. Name 3 classmates with whom you would not like to make pairs to take part in the dynamic game "Pass the ball". Name them in order of dislike;

- progress of the dynamic game;

- the second phase: applying the same questionnaire after playing the game; each student is asked again to list 3 choices and 3 dislikes, this time being aware of the teammates' potential in the dynamic game "Pass the ball".

The two tests were assessed by writing the information in a sociometric matrix with the help of which the sociometric indices were calculated; it was thus created the collective sociogram reflecting the types of interpersonal relationships, their value as well as the level of group cohesion on the basis of the following formulas (Zlate \& Zlate, 1982):

- preferential status index (PSI);

PSI $=\frac{\text { (No. of elections }- \text { No. of re jections) received by } x}{N(\text { number of group members })-1}$

- sociometric status index (SSI);

$\mathrm{SSI}=\frac{\text { No. of elections reveived by } x}{\text { N(number of group members })-1}$

- group cohesion index (GCI) (Matei, 1973)

$\mathrm{GCI}=\frac{\left(\mathbf{p}_{\mathrm{x}}^{0,5}+\mathbf{p}_{\mathrm{y}}^{1}+\mathbf{p}_{\mathrm{z}}^{1,5}\right)-\left(\mathbf{r}_{\mathrm{x}}^{0,5}+\mathrm{r}_{\mathrm{y}}^{1}+\mathbf{r}_{\mathrm{z}}^{1,5}\right)}{N(p x+p y+p z+r x+r y+r z)}$

\section{Results}

The results and analysis were based on recording and processing the sociogram responses to the two tests.

1. Comparative analysis of the results for the sociometric test "My own opinions"

On the basis of the processed responses and counted with the help of the sociometric matrix, the favourite index of each student in all tested classrooms was calculated and the collective sociogram of mutual choices and rejections (Figures 1-3) was developed. The median of 
choices and rejections was also calculated to establish its type for each student and determine the level of group cohesion for each classroom.
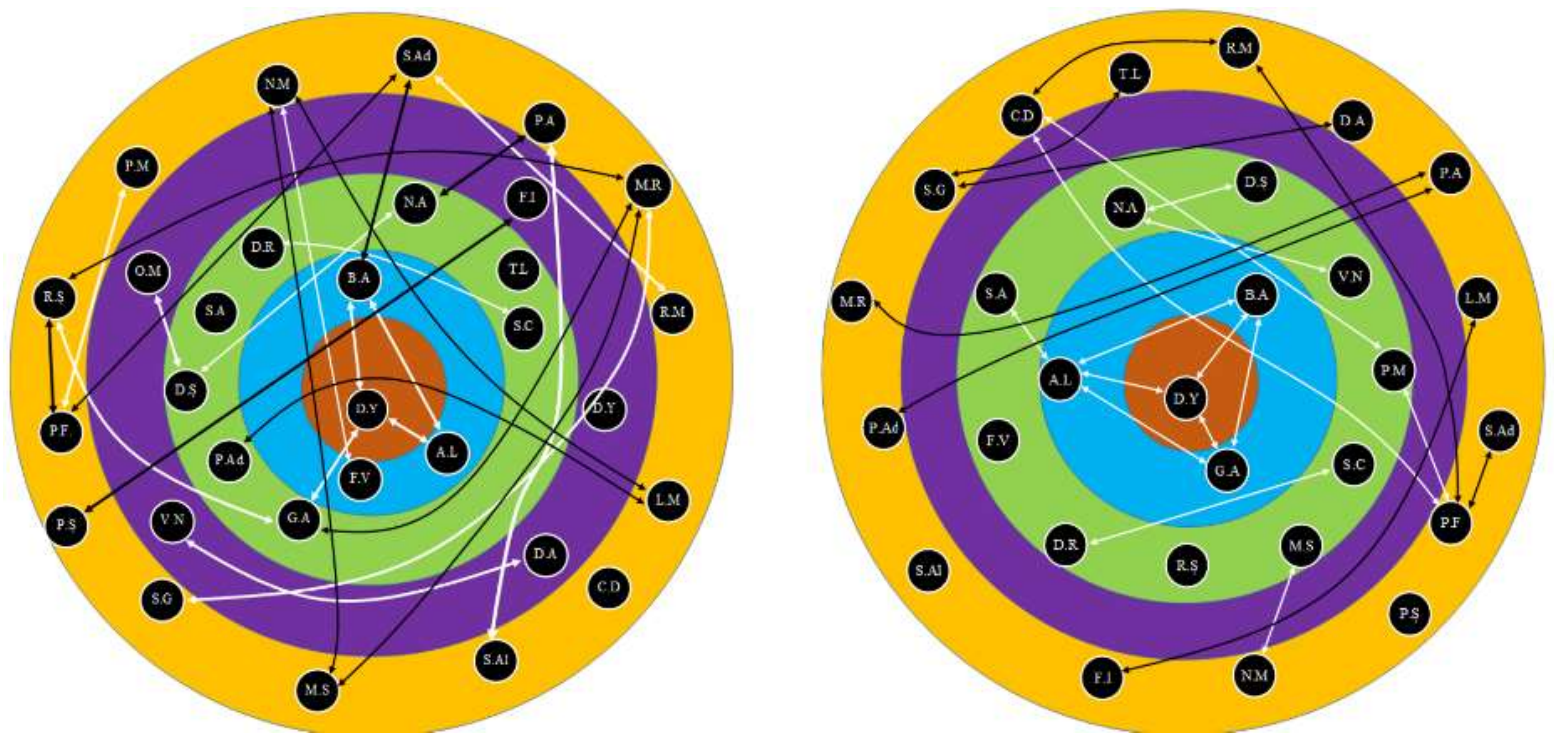

Figure 1. Sociogram for the second-grade classroom, Middle School no. 6, Pitești - "My own opinions", IT, FT
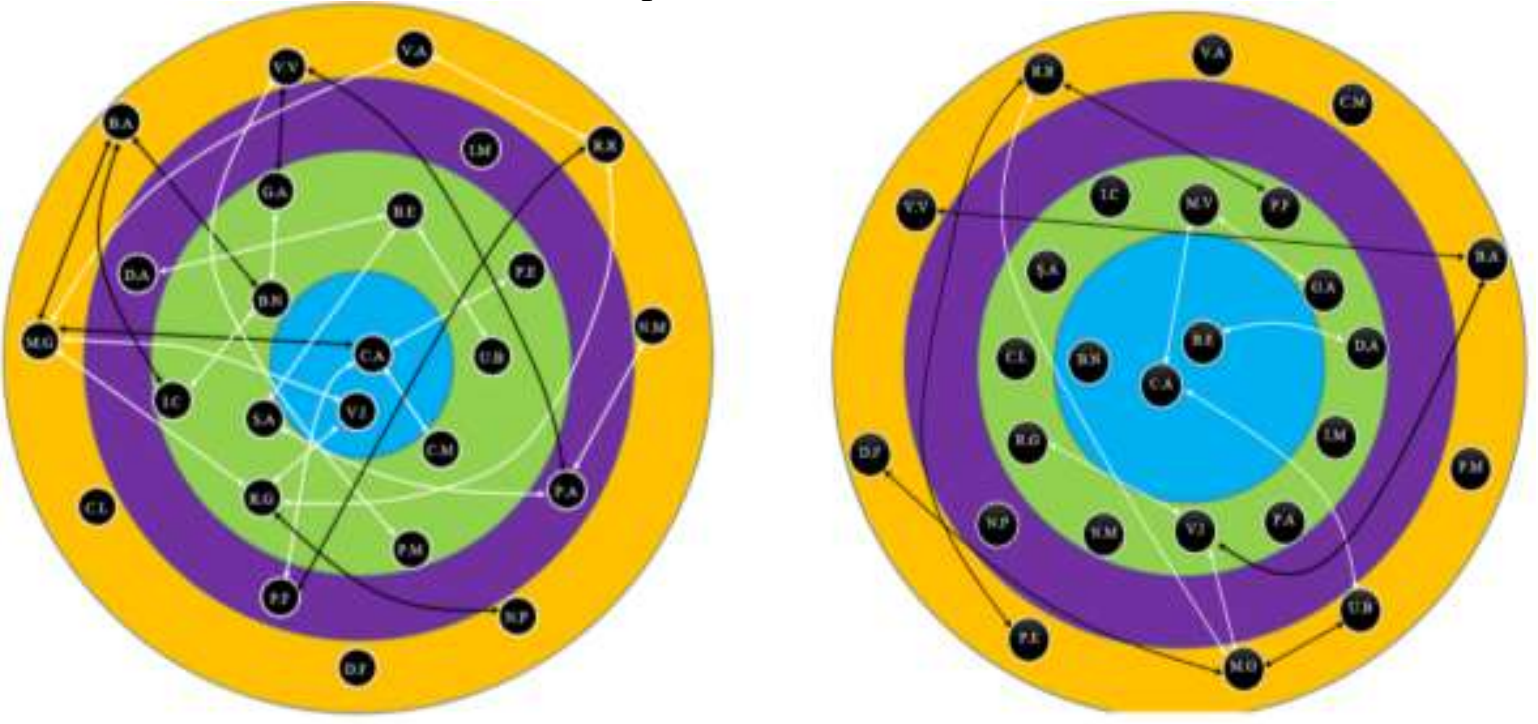

Figure 2. Sociogram for the second-grade classroom, Middle School no. 16, Pitești - "My own opinions", IT, FT 

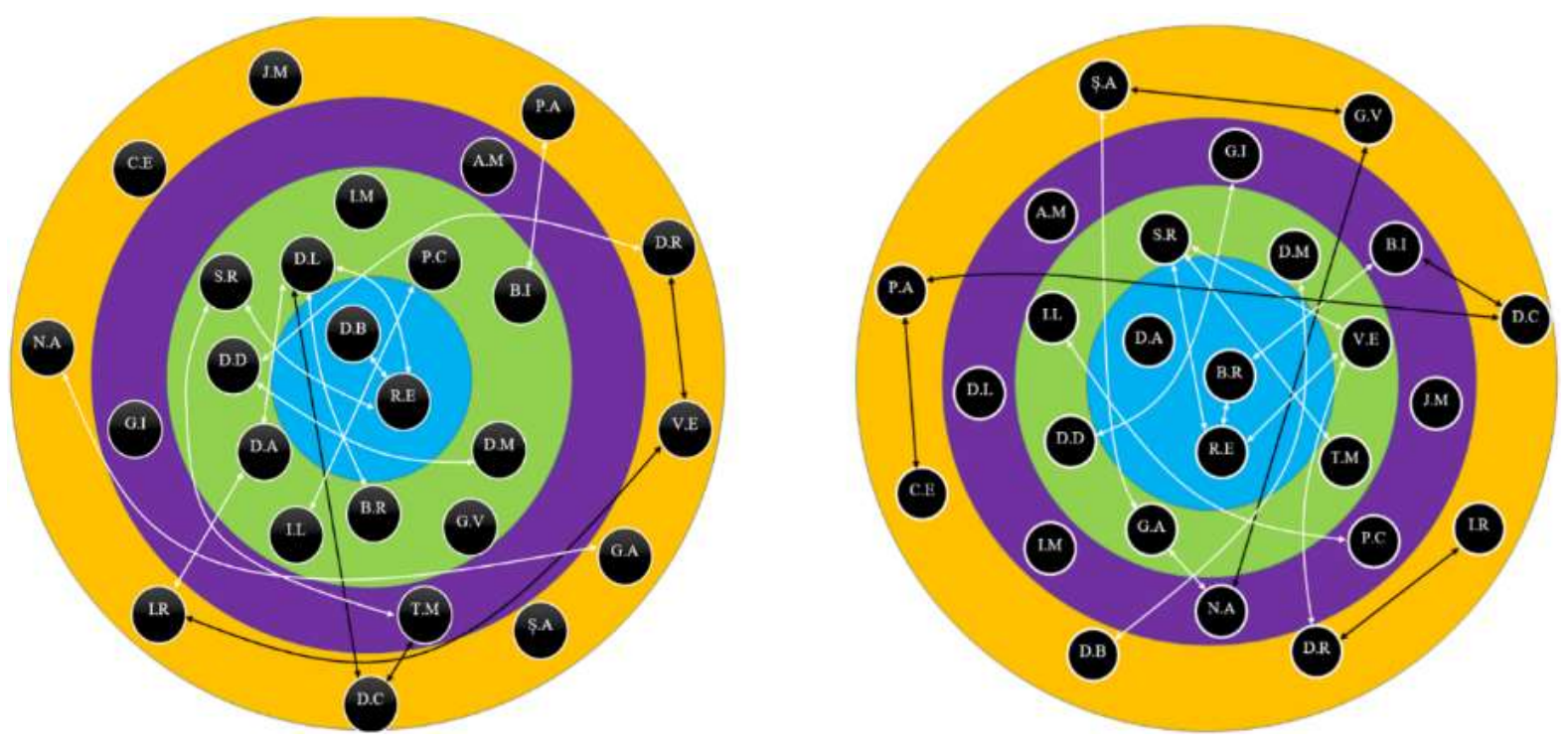

Figure 3. Sociogram for the second-grade classroom, Middle School no. 1, Costești - "My own opinions", IT, FT

By comparing the results of the two tests, we found that, throughout the research, the physical education class with contents from the dynamic games had a social impact on increasing group cohesion (Matei, 1973).

Thus, we have noticed the following aspects (Figure 4):

- in the IT, the cohesion level for the second-grade classroom from School no. 6, Pitești, records the index -0.01 , which indicates a disorganised group in terms of cohesion, while in the FT, the cohesion level reaches 0.07 , which turns the classroom into a group with weak cohesion.

- in the IT, the cohesion level for the second-grade classroom from School no. 16, Pitești, records the index 0.06, which indicates a group with weak cohesion, while in the FT, the classroom makes progress towards a group with emerging cohesion.

- in the IT, the cohesion level for the second-grade classroom from School no. 1, Costești, records the index 0.12 , which indicates a group with weak cohesion, while in the FT, the index is 0.21 , which turns the classroom into a group with emerging cohesion. 


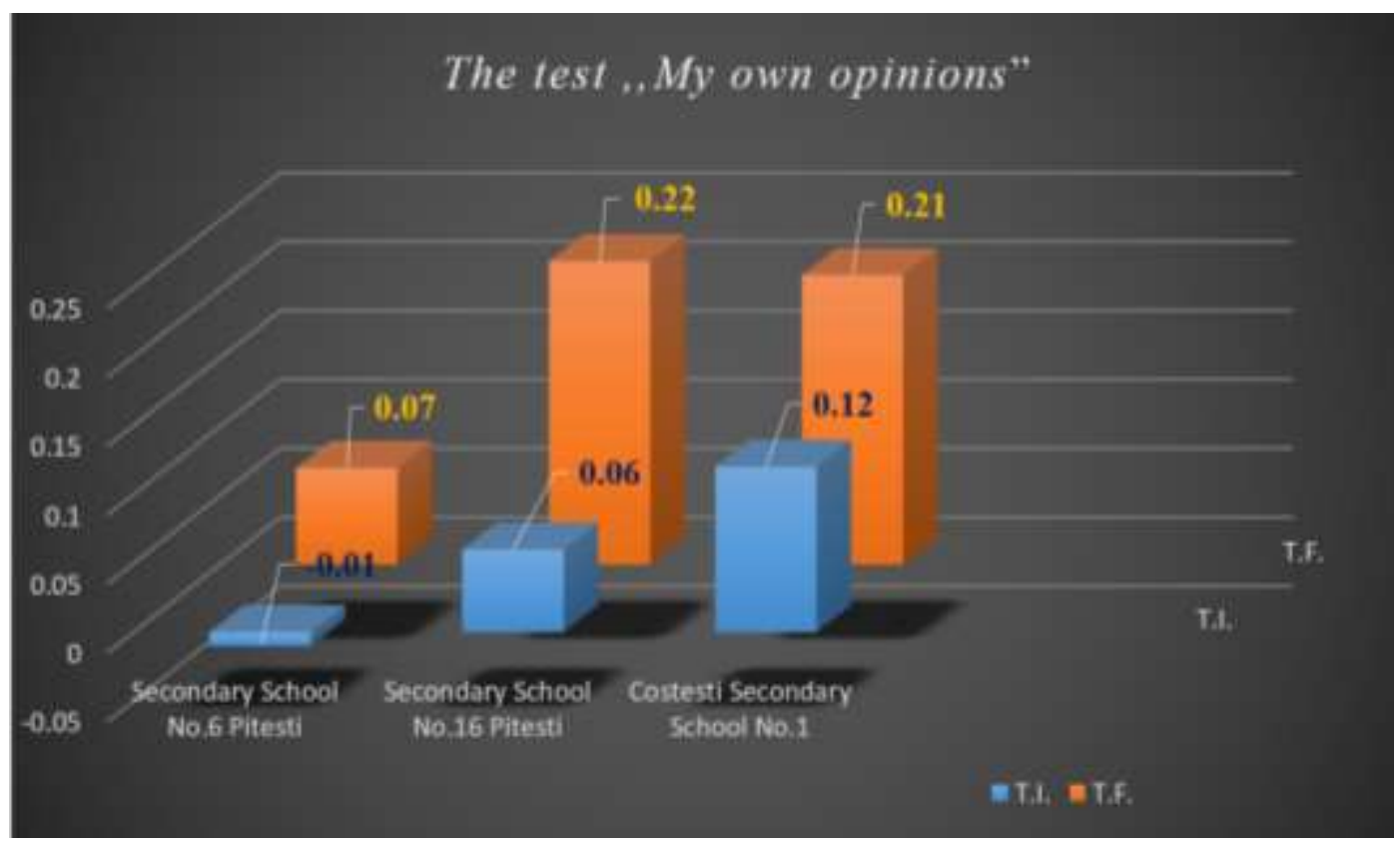

Figure 4. GCI values for the three second-grade classrooms - "My own opinions", IT, FT

This test was not created to refer to the motor activity, but to the level of student interaction before starting the experiment, without considering the active character of the physical education content.

From the progress of cohesion levels, we can notice that the implementation of the instructive-educational design for building an interrelation behaviour, added to students' psychometric skills, reflects the development of their social behaviour spirit, which is maintained in other possible activities.

This progress is confirmed by calculating the significance of the differences between the two tests. In this respect, in the test "My own opinions", the t-value has a huge significance, being 2 for $\mathrm{f}=\mathrm{n}-1=81-1=80$ degrees of freedom $(\mathrm{n}=$ total number of students in the three classrooms) and corresponds to a limit value of 0.05 , equivalent to a probability of $95 \%$, where the t-value is 1.96 (Fischer's Table - Dragnea, 2002).

2. Comparative analysis of the results for the sociometric test "My own revised/changed opinions"

To analyse the results of this test, the same presentation of the information in the sociometric matrix was preserved in order to establish the preferred index, from which the collective sociograms of mutual preferences and rejections emerged. Figures 5-7 show the collective sociograms in the IT and FT for the first phase of the test, while Figures 8-10 show the IT and FT in the second phase of the test. 

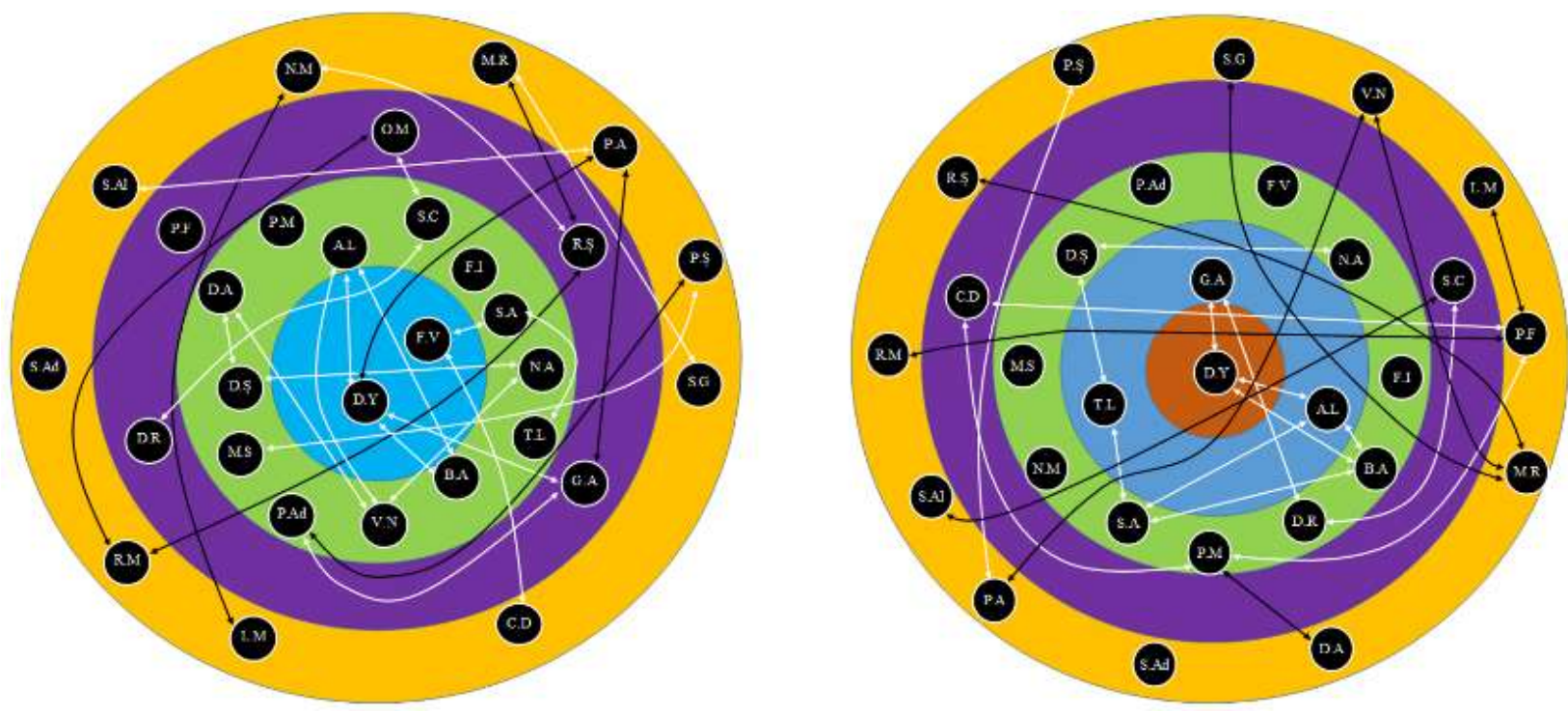

Figure 5. Sociogram for the second-grade classroom, Middle School no. 6, Pitești - "My own revised/changed opinions", phase I, IT, FT
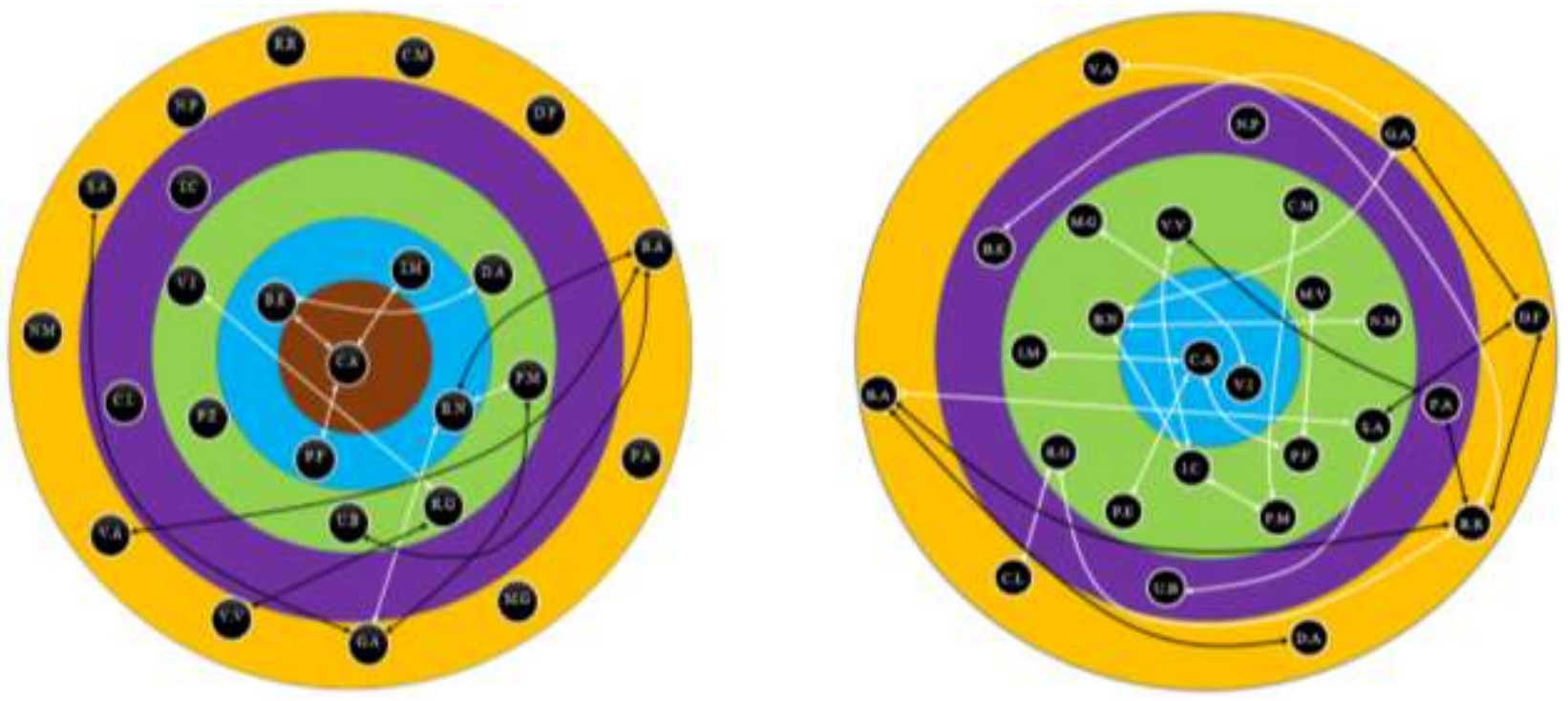

Figure 6. Sociogram for the second-grade classroom, Middle School no. 16, Pitești - "My own revised/changed opinions", phase I, IT, FT 

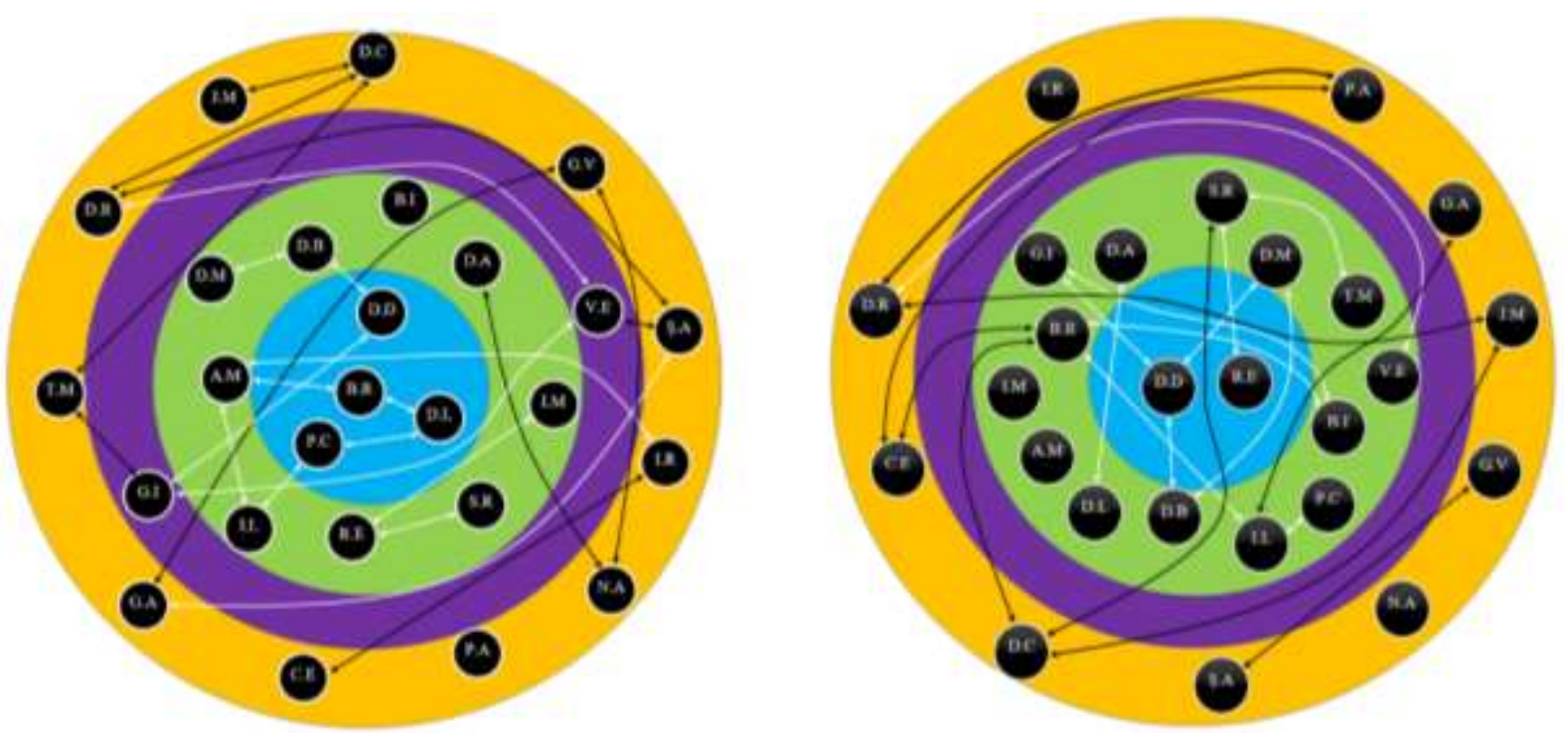

Figure 7. Sociogram for the second-grade classroom, Middle School no. 1, Costești - "My own revised/changed opinions", phase I, IT, FT
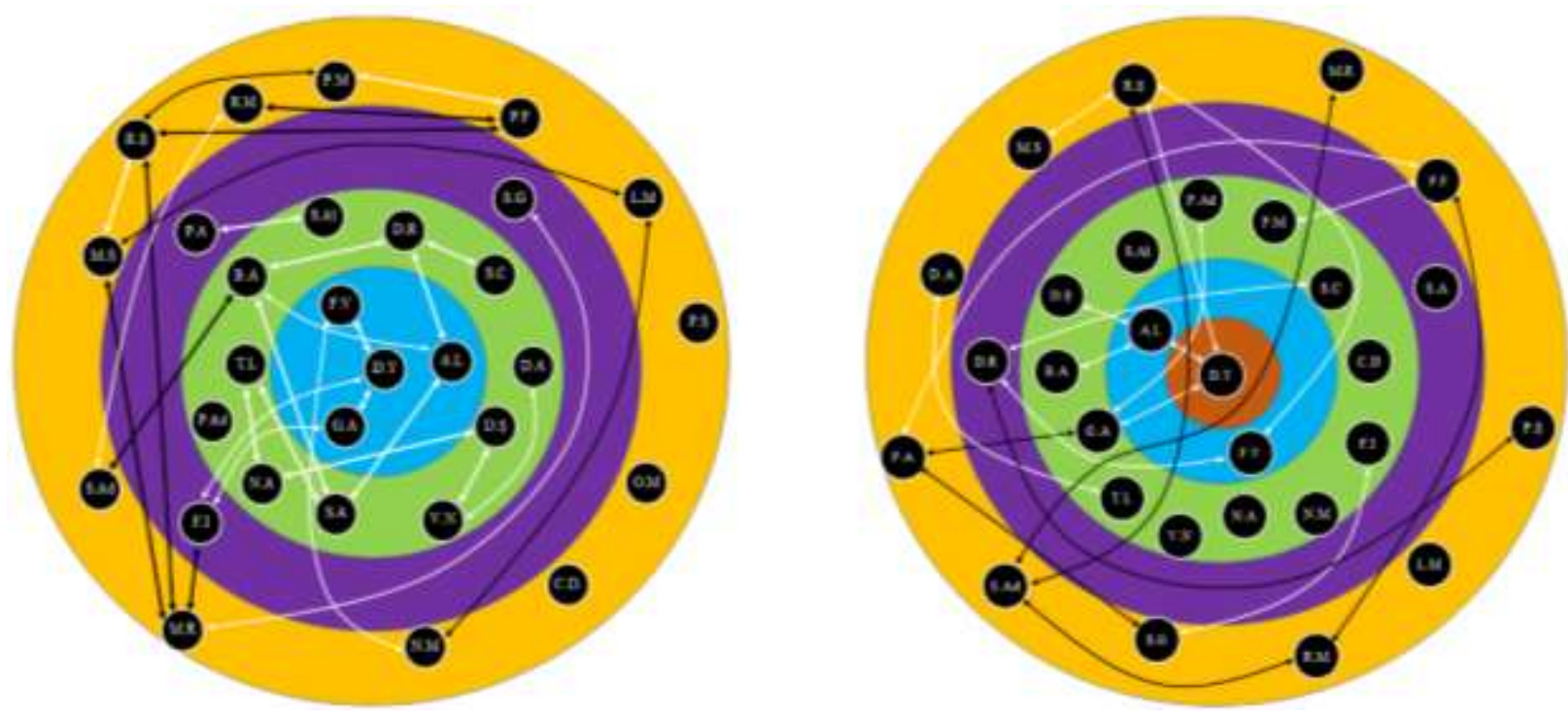

Figure 8. Sociogram for the second-grade classroom, Middle School no. 6, Pitești - "My own revised/changed opinions", phase II, IT, FT 

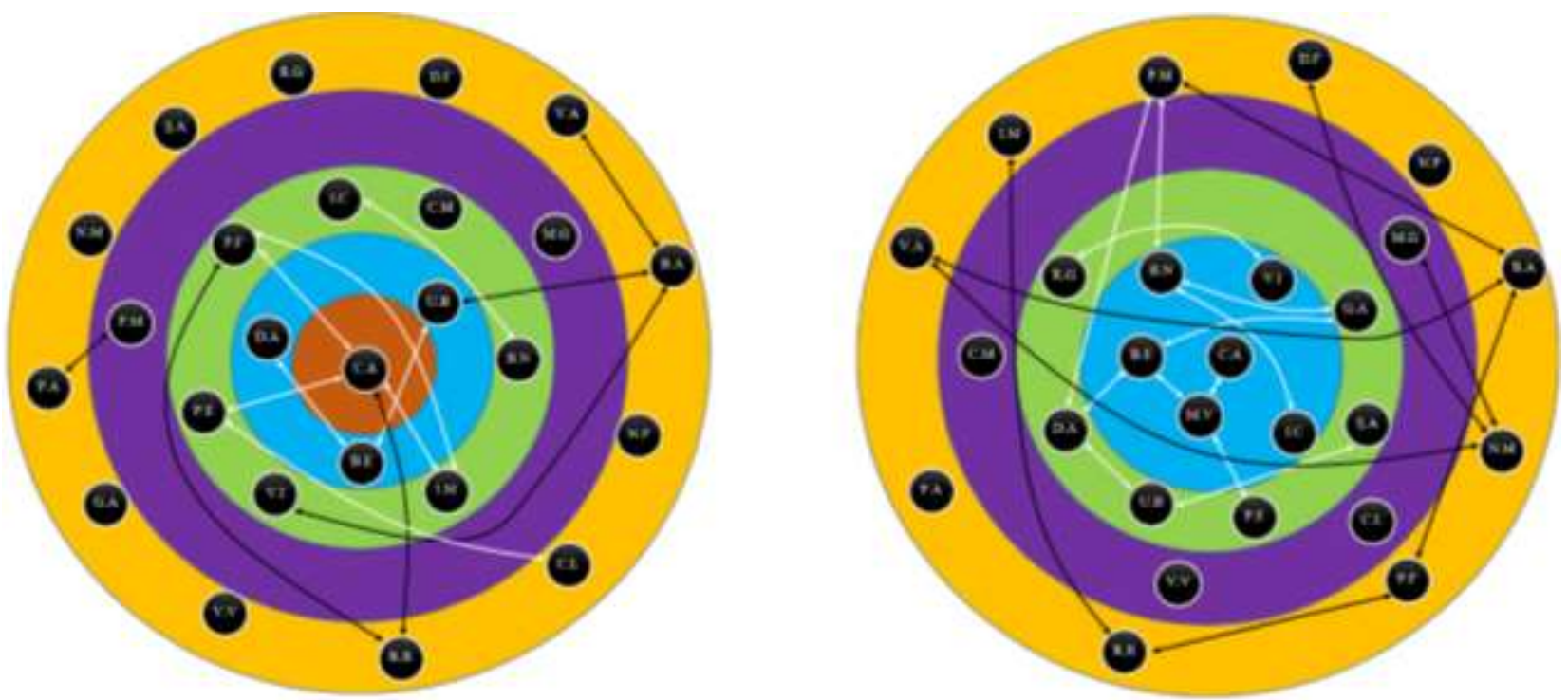

Figure 9. Sociogram for the second-grade classroom, Middle School no. 16, Pitești - "My own revised/changed opinions", phase II, IT, FT
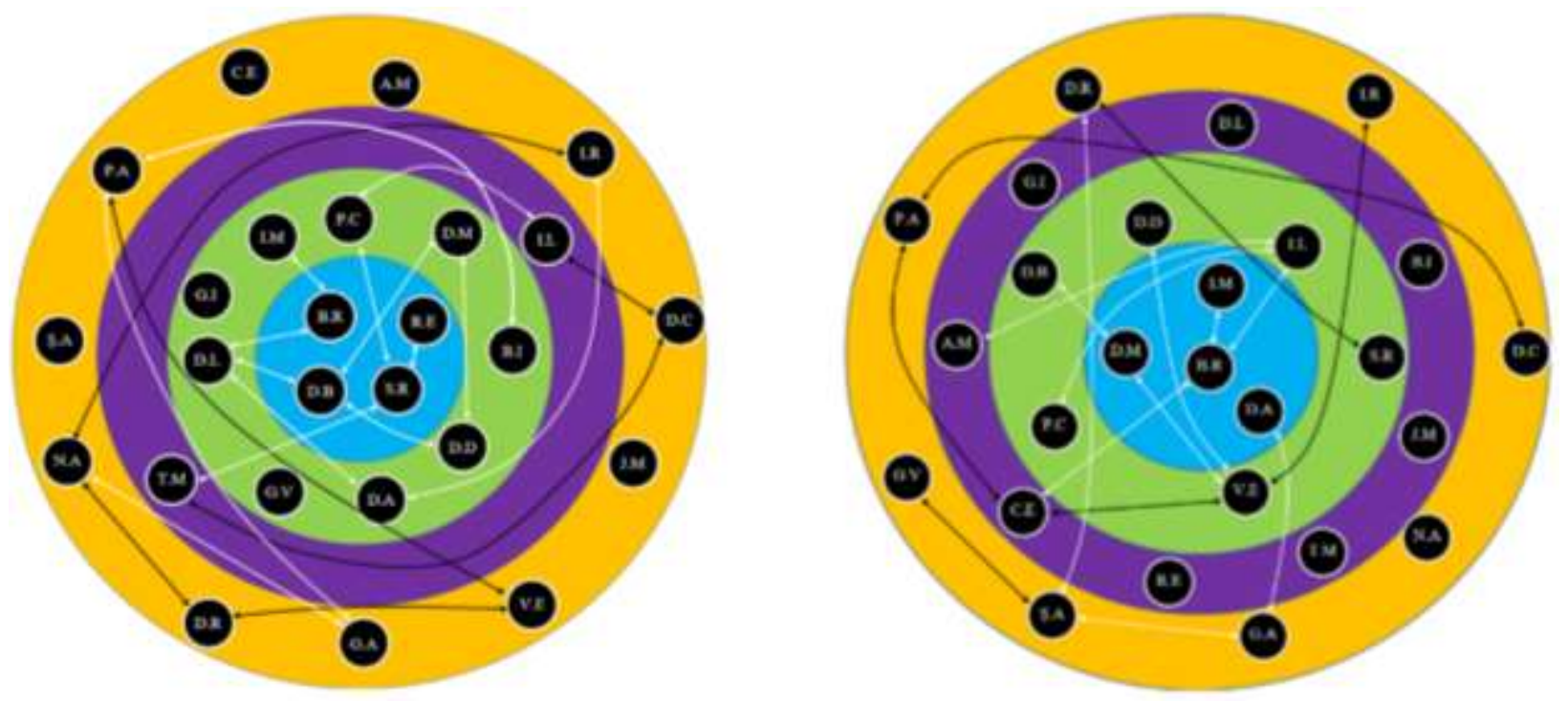

Figure 10. Sociogram for the second-grade classroom, Middle School no. 1, Costești - "My own revised/changed opinions", phase II, IT, FT

In order to establish preferences and rejections, the median was calculated to determine the cohesion index.

By means of this sociometric test applied in two phases, we verified the efficiency of dynamic games in building prosocial behaviour through changes in students' interpersonal relationships during the process of developing social climate cohesion. The test was applied at the beginning (December 2018) and the end of the research (May 2019):

- the initial test (IT):

- phase I, before the game, to identify the initial level of interaction; 
- phase II, after the game, to identify changes that occurred after applying one single game and to obtain immediate data;

- the final test (FT):

- phase I, before the game, after introducing the instructive-educational design;

- phase II, after the game, at the end of the experiment, to notice the impact of the didactic strategy on the formation of intended general skills, namely the "Shaping of socioemotional behaviour based on the feelings of friendship, collaboration and cooperation in the psychomotor activity", in the researched direction.

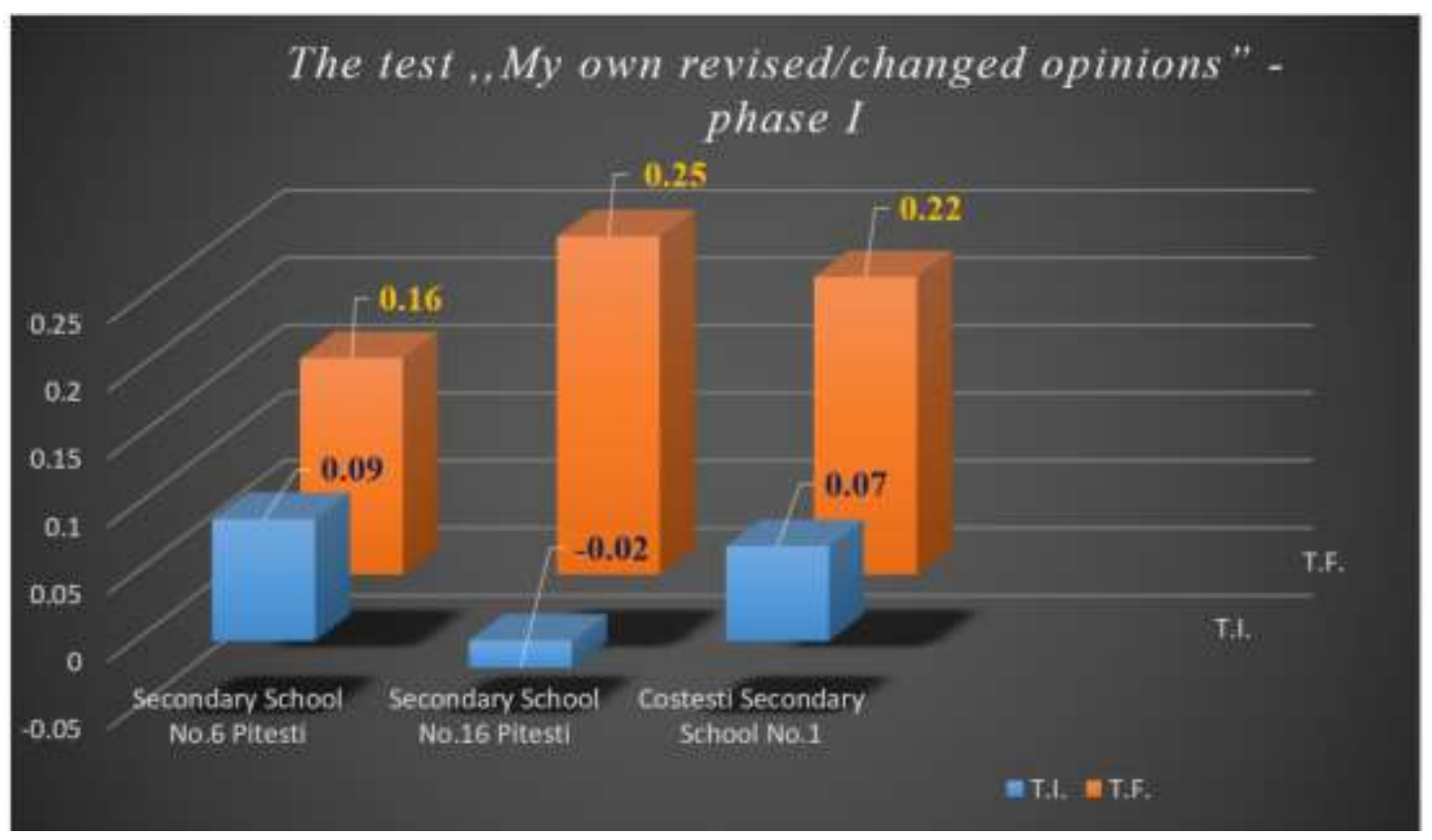

Figure 11. GCI values for the three second-grade classrooms - "My own revised/changed opinions" - phase I, IT, FT

By comparing the results in their dynamic during the research, we have observed the following situations in phase I of the test (Figure 11):

- in the IT, the cohesion level for the second-grade classroom from School no. 6, Pitești, records the index 0.09 , which indicates a group with weak cohesion, while in the FT, we can notice the development of cohesion, with an index of 0.16 , the group maintaining the same weak cohesion;

- in the IT, the cohesion level for the second-grade classroom from School no. 16, Pitești, records the index -0.02 , which indicates a disorganised group in terms of cohesion, while in the FT, the classroom makes progress towards a group with emerging cohesion, the index having the value 0.25 ;

- in the IT, the cohesion level for the second-grade classroom from School no. 1, Costești, records the index 0.07, which indicates a group with weak cohesion, while in the FT, the classroom turns into a group with emerging cohesion, the index having the value 0.22.

In order to see if the progress of the cohesion for the three second-grade classrooms was significant, the significance of the differences between the achieved tests was calculated. Thus, 
for phase $\mathrm{I}$ of this test, the $\mathrm{t}$-value is 2 for the same degree of freedom $\mathrm{f}=80$, which corresponds to a probability of $95 \%$, a limit value of 0.05 , so the $t$-value is significant.

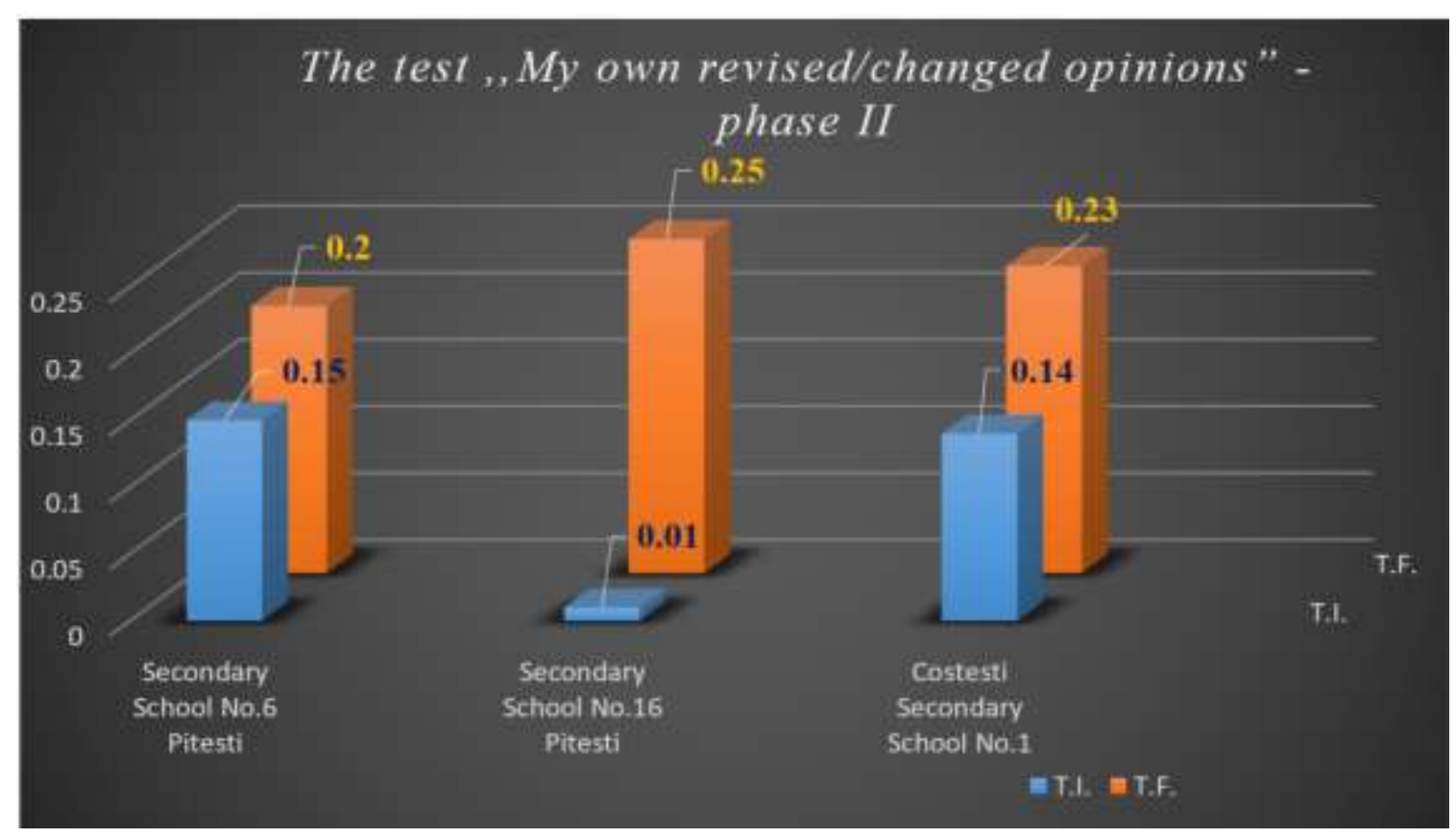

Figure 12. GCI values for the three second-grade classrooms - "My own revised/changed opinions" - phase II, IT, FT

In the same way, we calculated the data obtained in phase II of the test "My own revised/ changed opinions" by comparing the results of the initial and final tests for this phase (Figure 12):

- the initial test for School no. 6, Pitești, shows a value of 0.15, the classroom having weak group cohesion, while in the final test, the value increases to 0.20 , but group cohesion still remains weak;

- the initial test for School no. 16, Pitești, shows a value of 0.01 , which indicates some group cohesion, while in the final test, the cohesion level is 0.25 , which turns the classroom into a group with emerging cohesion;

- the initial test for School no. 1, Costești, shows a value of 0.14, which indicates the same weak group cohesion, while in the final test, the cohesion level is 0.23 , which turns the classroom into a group with emerging cohesion.

The significance of the progress involving the cohesion level of the groups at the end of the experiment is confirmed by the $\mathrm{t}$-value $=2$, which is higher than in Fischer's Table for the same degree of freedom $\mathrm{f}=80$, corresponding to a probability of $95 \%$, the limit of the significance being 0.05 .

The positive evolution of the dynamic group cohesion for the three classrooms emphasises the contribution and impact of the motor activity content used in the physical education class, with a probability of 95\%, on optimising students' socialisation skills and improving the social climate of the school group. 
After analysing and comparing the final data with the initial ones obtained through the two tests following the application of the didactic strategy, it was concluded that interpersonal relationships between students have reached a level of social maturity in school; thus, the group cohesion is reflected in the unity of the group rather than the person, and the students' personality manifests a socio-emotional intelligence expressed by their understanding and acceptance of the behaviours of others for positive interaction.

The practice of motor activity in the school environment during the physical education lesson should be considered an important mechanism of the educational process, in the formation and development of team life. Through the content of the physical education lesson intended for the formation and development of motor skills, the training and education of the skills necessary for social interaction is also performed.

\section{Conclusion}

The basic acquisition school cycle can generate a prosocial skill during the physical education class when the didactic strategy is focused on the role of the game and all thematic steps are developed with the help of selected means exclusively belonging to the categories of dynamic games and sport routes for the content domain "Development of personality features", while the organising steps of a lesson make the interpersonal relationships easier, for instance help, support, encouragement, etc.

The sociometric method highlighted the emotional involvement of students in the physical education lesson that, through age-specific dynamic games, contributed to the formation/ adjustment/development of the prosocial behaviour necessary for their integration into the group/society.

The adaptation of this assessment method to the particularities of students and the content of the instructive-educational means facilitated an objective and efficient evaluation of the activity specific to the school physical education subject.

It was found that both improving students' interpersonal relationships through the dynamic value of attraction and rejection during the research and increasing the level of group cohesion demonstrates the fairness of establishing a general competence in the social sphere and its operationalisation through specific competencies during the acquisition cycle.

The results of this research highlight the valences of the instructive-educational process for the physical education school subject, of formal motor activities in the process of educating children's ability to socialise, a process that should begin early and continue progressively as children get older.

\section{References}

Cârstea, G. (1981). Sociologia sportului [Sports sociology]. București: IEFS.

Diamond, A. (2007). Interrelated and interdependent. Developmental Science, 1(10), 152-158. https://dx.doi.org/10.1111\%2Fj.1467-7687.2007.00578.x

D'Isanto, T. (2019). State of art and didactics opportunities of physical education teaching in primary school. Journal of Physical Education and Sport, 19(5), 1759-1762. https://doi.org/10.7752/jpes.2019.s5257 
Dragnea, A. (2002). Măsurare și evaluare în activitățile motrice [Measurement and evaluation in motor activities]. Pitești: Editura Universității din Pitești.

Ivanova, N., \& Timoshina, E. (2012). Principles of formation of foundations of senior preschool children's social activity. Procedia - Social and Behavioral Sciences, 146, 385389. https://doi.org/10.1016/j.sbspro.2014.08.135

Lupu, E. (2011). The role of motor activities in the psychomotor development of preschool children - future pupils. Procedia - Social and Behavioral Sciences, 12, 457-464. https://doi.org/10.1016/j.sbspro.2011.02.056

Lupu, I. (2006). Calitatea vieții în sănătate. Definiții și instrumente de evaluare [Quality of life in health. Definitions and assessment instruments]. Calitatea vieții, 17(1-2).

Matei, N. C. (1973). Sociabilitatea și temeiurile ei morale in colectivele școlare [Sociability and its moral grounds in school groups]. București: Editura Didactică și Pedagogică.

Mihăilescu, L., \& Mihăilescu, L. (2017). Contributions regarding the establishment of the relation between competences - content areas - fundamental acquisitions cycle. Journal of Physical Education and Sport, 17(5), 2266-2269. DOI: 10.7752/jpes.2017.s5241

Mijaică, R. (2015). Motor games, social learning alternative content in physical education lesson. Procedia - Social and Behavioral Sciences, 180, 1289-1296. https://doi.org/10.1016/j.sbspro.2015.02.266

Mijaică, R. (2016). Optimization of group cohesion through restructuring social networks by using motor skill games in physical education lesson. Gymnasium - Scientific Journal of Education, Sports and Health, 17(2). http://www.gymnasium.ub.ro/index.php/journal/article/view/48/44

Plăstoi, C. D., \& Buțu, I. (2018). Sports education and its impact on the health and integration into society. The European Proceedings of Social \& Behavioural Sciences, 67, 1350-1358. https://doi.org/10.15405/epsbs.2019.08.03.166

Rukavishnikova, E. E. (2016). Specific psychological characteristics of interpersonal relationships in preschool children. Procedia - Social and Behavioral Sciences, 233, 118122. https://doi.org/10.1016/j.sbspro.2016.10.159

Sopa, I. S., Sanislav, M., \& Pomohaci, M. (2014). The importance and utility of the sociometric survey method in physical education research. Procedia - Social and Behavioral Sciences, 117, 182-192. https://doi.org/10.1016/j.sbspro.2014.02.199

Tudorache, G., \& Mihăilescu, L. (2018). Research for continuity of social integration from preschool education to primary cycle. The European Proceedings of Social \& Behavioural Sciences, 67, 1815-1822. https://doi.org/10.15405/epsbs.2019.08.03.223

Urichianu, B. A. (2017). Menținerea stării optime de sănătate și creșterea capacității de adaptare la factorii de mediu, obiectiv de referință al educației fizice școlare [Maintaining optimum health and increasing the ability to adapt to environmental factors, a reference objective of school physical education]. În A 10-a Sesiune Internațională de Comunicări Științifice "Rolul educației fizice și sportului în promovarea unui stil de viață sănătos" (pp. 54-58). București: Editura Universității din București.

Usinski, K. D. (1956). Opere pedagogice alese [Selected pedagogical works] (Vol. 1). București: Editura de Stat Didactică și Pedagogică.

Vasiliu, A. M. (2015). Study on promoting quality of life through physical exercise. Procedia - Social and Behavioral Sciences, 180, 1439-1443. https://doi.org/10.1016/j.sbspro.2015.02.290

Zlate, M., \& Zlate, C. (1982). Cunoașterea și activarea grupurilor sociale [Knowledge and activation of social groups]. București: Editura Politică. 